\title{
Implementation Of The Natural Rural Community Empowerment Program (PNPM) In Ompu Raja Village, East Hutapea Laguboti District-Toba Samosir Regency
}

Friska M Sinaga

Department of State Administration Science, University Of North Sumatra, Indonesia.

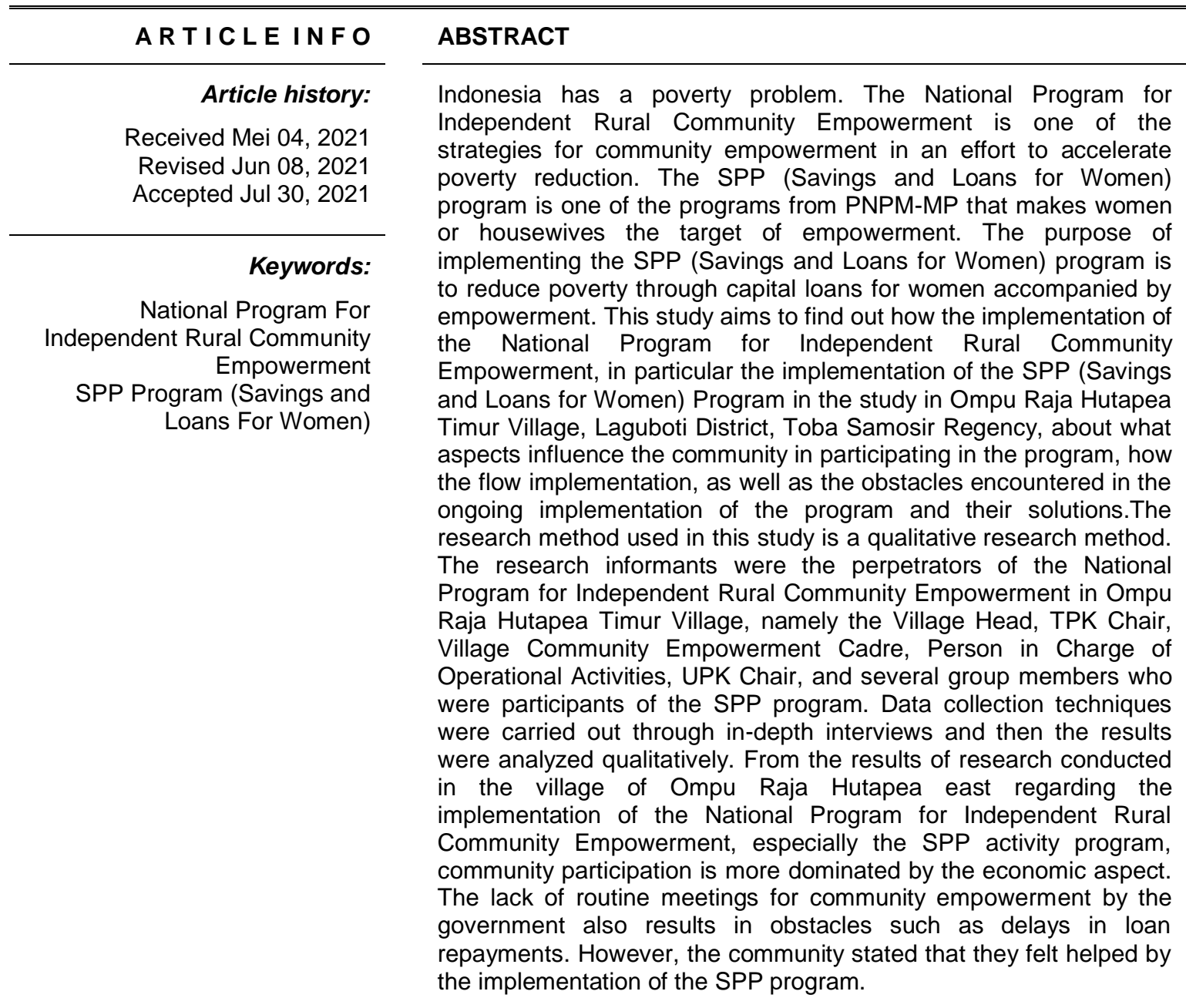

This is an open access article under the CC BY-NC license.

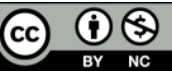

\section{Corresponding Author:}

Friska M Sinaga,

Department of State Administration Science,

University Of North Sumatra, Indonesia,

JI. Dr. Mansur No. 9 Padang Bulan, Kec. Medan Baru, Kota Medan 20222.

Email: friskasinaga@gmail.com 


\section{INTRODUCTION}

In 2007, the implementation of PNPM Mandiri in Rural Areas reached 26,724 villages from 1,837 sub-districts in 32 provinces. In 2008, PNPM Mandiri in Rural Areas was implemented in 34,031 villages out of 2,230 sub-districts in 32 provinces. In 2009, it was implemented in 50,201 villages from 3,908 sub-districts in 32 provinces in Indonesia and in 2010 covered 4,805 sub-districts in 32 provinces in Indonesia or approximately 75.9 percent of the total PNPM Mandiri locations.

The amount of the allocated cost is around Rp. 750 million to Rp. 3 billion per sub-district, depending on the population. PNPM Mandiri in Rural Areas is under the guidance of the Directorate of Community and Village Empowerment (PMD), the Ministry of Home Affairs. PNPM Mandiri Rural itself is integrated for the construction of community facilities and facilities in rural areas through physical activities and also activities to improve the economic standard of the community, namely through the Savings and Loans program for Women's groups (SPP).

One of the programs from the National Program for Independent Rural Community Empowerment is SPP (Savings and Loans for Women's groups). The SPP (Savings and Loans for Women's Group) program is one of the poverty reduction programs through the concept of community empowerment, especially for women. Through the SPP program (Savings and Loans for Women's groups), women who are divided into several groups have the potential to improve the economic level of their families through independent businesses from the capital they receive from the SPP program.

Ompu Raja Hutapea Timur Village is one of the villages targeted by PNPM Mandiri in Rural Areas. Ompu Raja Hutapea Timur Village is one of the villages in Laguboti District which separated from Ompu Raja Hutapea Village in 2010. Ompu Raja Hutapea Village consists of 6 hamlets, namely Lumban Balian, Lumban Sioa, Lumban Nabolon, Lipaek, Siarung-arung and Simatupang, where PNPM Mandiri in Rural Areas has been implemented since 2010 since the village was independent. The total population of Ompu Raja Hutapea Timur Village as of December 2013 was $375 \mathrm{KK}$ (Head of Families) or about 1,002 people and was still dominated by the poor, i.e. $220 \mathrm{KK}$ (Heads of Families) most of whom were farmers, The implementation of PNPM Mandiri in Rural Areas, especially in the SPP program in Ompu Raja Hutapea Timur Village, was distributed unevenly, namely there were only 4 hamlets out of 6 hamlets in Ompu Raja Hutapea Timur Village that participated in the SPP program, and each group consisted of 16 people, 13 people, 12 people and 9 people. (source: Village Archives of Ompu Raja Hutapea Timur).

Based on the explanation above, the authors feel interested in conducting research on the implementation of PNPM Mandiri in Rural in terms of the implementation process, benefits and orientation of the implementation of PNPM Mandiri in Rural Areas, namely whether it is oriented to the institutional/empowerment aspect or the economic aspect.

\section{RESEARCH METHOD}

The research method used by researchers in this study is a qualitative research method. Qualitative research method is a research method used to examine the condition of natural objects, where the researcher is the key instrument, the data collection technique is done by triangulation (combined), the data analysis is inductive, and the results of qualitative research emphasize meaning rather than generalization. Objects in qualitative research are natural objects, or natural settings. Natural objects are objects as they are, not manipulated by the researcher so that the conditions at the time of research enter the object. In qualitative research, data collection is not guided by theory, but is guided by facts found during research in the field. Therefore, data analysis is carried out and can then be constructed into a hypothesis or theory.

Thus, this study will describe the facts and explain the state of the object of research based on the existing facts and try to analyze the truth based on the data obtained in the field. The research method used in this study is a qualitative research method. The use of qualitative research methods in this study is for the reason that researchers want to know in depth how the implementation of PNPM Mandiri in Rural Areas is carried out in Ompu Raja Village, East Hutapea, especially in the SPP activity program (Savings and Loans for Women's groups). This will certainly 
be answered more clearly if it is done by interviewing the parties concerned or in this case called the informant in depth (in-depth interview), of course by interacting with the informants.

Qualitative research methods have advantages in the research process because they are holistic (comprehensive) and dynamic, there is a reciprocal relationship or interaction between the researcher and the researched. In addition, this qualitative research method also emphasizes meaning, making it easier for readers to understand what the problems and concepts found in this research are. Furthermore, to expedite the research process, the researchers will always build a rapport (good relationship) with the community, PNPM Mandiri Rural actors and the village government.

\section{RESULTS AND DISCUSSIONS}

\subsection{Informants' Understanding of PNPM-MP Especially the SPP Program}

In presenting the data, it was stated that the informant's understanding of the National Program for Independent Rural Community Empowerment, especially the SPP Program, was one of the government programs aimed at alleviating poverty by providing capital loans with a declining interest system based on women's empowerment. From the informants' understanding of the SPP Program, it is more focused on its economic value or economic orientation. The community feels more helped by the existence of capital loans by the government rather than empowerment oriented, especially women participating in the SPP Program who are able to increase their empowerment and develop the potential of the SPP Program participants. The emphasis on economic meaning is due to the fact that The concentration of the poor in Indonesia is more in rural areas, especially the poor in North Sumatra. This affects the public's view that the most important thing for them is the existence of economic assistance from the government. The community's paradigm of welfare is still based solely on the economy, where people still assume that if their economy is good, then they are already prosperous.

The types of activities that are funded by rural PNPM Mandiri are activities to develop or repair basic facilities and infrastructure that can provide economic benefits to the community, activities to improve health and education services, activities to increase skills of economic business groups and increase savings and loan capital for women's groups. (SPP). From the results of interviews with informants, it can be concluded that the community knows the types of activities financed by PNPM Mandiri Rural. However, the community is more aware of it in the form of physical development such as road construction, agricultural irrigation development and non-physical development such as SPP.

The basic objectives and principles of PNPM Mandiri in Rural Areas exist 12 principles and have been explained in the previous chapter, namely in chapter II. Based on the data obtained by the researchers above, it can be concluded that not all people know the principles of PNPM Mandiri in Rural Areas. Most people only know empowerment and/or community participation as a principle rather than PNPM Mandiri in Rural Areas. The community should know and understand more about the basic principles of PNPM Mandiri because it is a reference in carrying out PNPM Mandiri activities to achieve the objectives of implementing government policies, especially for PNPM Mandiri in Rural Areas.

\subsection{The Implementation of the SPP Activity Program is One of the Community Empowerment Strategies}

The SPP activity program which is one of the government policies using an empowerment approach to the community is assessed. In empowering the community, the thing that needs to be considered is the involvement of the empowerment actors, namely the empowering party and the empowered party. Community empowerment can be done with intense involvement between the two parties so that the goals of empowerment can be achieved properly.

Based on the theory put forward by the expert above regarding community empowerment, the implementation of the SPP activity program carried out in the village of Ompu Raja Hutapea Timur can be said to be a form of community empowerment. As has been explained in the research 
findings chapter, namely regarding the implementation of the SPP program in the village of Ompu Raja Hutapea Timur, starting from deliberations between villages for socialization, exploring ideas, planning, submitting proposals, determining proposals, to determining SPP capital loan interest, all of which involve the community. agreed upon by mutual consensus. In this case, it can be seen the importance of community involvement as an empowered party where the empowering party or government can know and hear directly what the community needs. Seeing how the problems that occur in the community are related to the use of the capital that has been provided, management, obstacles and also formulating together what are the problem solving strategies or obstacles encountered by the community in developing their empowerment. Thus, coaching or empowerment will be able to take place continuously and sustainably.

\subsection{Implementation of the SPP Program as a Strategy for Women's Empowerment}

Implementation Program National Empowerment Public Independent in Rural Areas, especially the SPP activity program is directed at to tackle the problem of poverty by involving all elements of society, both men and women. In the sense that even though the implementation of the SPP activity program is aimed at empowering women or mothers as participants in the SPP activity program, men are still involved in the stages of each stage, from planning to evaluation.

Girls or people Mother made as target main. This empowerment activity is because according to the observations of researchers in the village of Ompu Raja Hutapea Timur, women are often the weaker party. Lack of access to politics, power in the household (gender issue), resulting in women or mothers inevitably having to balance the productivity of their husbands so that family needs can be met. Therefore, through this SPP activity program, women or mothers can be assisted in terms of capital loans and coaching and/or empowerment provided by empowerment actors and PNPM Mandiri Rural which can increase the empowerment and capabilities of these women.

\subsection{Application of PNPM-Mandiri Rural Principles in the Implementation of the SPP Activity Program}

The implementation of the SPP Activity Program as stated by the researcher above is a government policy program aimed at reaching the poor in rural areas, in accordance with the principle of being oriented towards the poor. This shows that the government is siding with the poor in order to eliminate the level of poverty in Indonesia.

Meetings and coaching and/or empowerment activities carried out in Ompu Raja Hutapea Timur Village are carried out regularly so that the community can be empowered and nurtured continuously so that they are able to become empowered, independent and competent communities, in accordance with the principles of Focusing on Human Development and are Sustainable. In addition, the SPP activity program is also in accordance with the principle of autonomy and the principle of decentralization where the participants of the SPP activity program in Ompu Raja Hutapea Village are also given the opportunity to increase their empowerment through the potential possessed by the community and regulate themselves how to manage development in their area without intervention by the community. parties so that they can be more independent.

The implementation of this SPP activity program is also one of the policies that prioritize poverty reduction in rural communities as the main priority of the policy. Each stage carried out in the implementation of the SPP activity program in the village of Ompu Raja Hutapea Timur was socialized in a language that is easy for the community to understand, as well as all the implementation procedures from submitting group proposals to payment methods, all in accordance with the Simple Principles of PNPM Mandiri Rural.

\section{CONCLUSION}

Savings and Loans for Women (SPP) is one of the government policies in tackling poverty through increasing community empowerment, especially mothers or women. Through increasing community empowerment, it is expected to be able to create an independent society that is prosperous and empowered for the process of human and economic development in a sustainable 
or continuous manner. The implementation of the SPP Activity Program in Ompu Raja Hutapea Village is motivated by the poverty conditions of the village community and the understanding that is influenced by patrilineal culture where women or mothers are also responsible for supporting the family economy.

The participation of village communities or women's groups who are SPP participants is mainly because they are more economically oriented, who think that if their economy is good, then they are already prosperous.

The implementation of the SPP Program in Ompu Raja Village, East Hutapea is carried out in accordance with the principles of PNPM Mandiri in Rural Areas which are the main guidelines for implementing the program. Starting from community outreach, group formation, to determining loan interest and payment terms, everything involve the community. This means that the decisions taken are democratically through community deliberation.

The SPP activity program is very helpful for the people of Ompu Raja Hutapea Timur Village in terms of supporting their economic life as an effort to get out of the scope of poverty through capital loans and coaching and/or empowerment. This is evident from the results of community interviewswhich stated that they were greatly helped after joining the program.

\section{REFERENCES}

Adisasmitha, Rahardjo. 2006. Pembangunan Pedesaan dan Perkotaan. Yogyakarta : Graha Ilmu.

Kartasasmita, Ginandjar. 1996. Pemberdayaan Masyarakat : Konsep Pembangunan Yang Berakar Pada Masyarakat. Jakarta ; Bappenas.

Prijono, Onny S. dan A.M.W. Pranarka. 1996. Centre for Strategic and International Studies. Pemberdayaan : Konsep, Kebijakan dan implementasi. Jakarta.

Singarimbun, Masri. 1995. Metode penelitian Survai. Jakarta: LP3ES

Soehartono, Irawan. 2008. Metode Penelitian Sosial. Bandung : PT Remaja Rosdakarya.

Sugiyono. 2008. Metode Penelitian Bisnis. Bandung : CV. Alfabeta Sugiyono. 2008. Memahami Penelitian Kualitatif. Bandung: CV. Alfabeta.

Sumodiningrat, Gunawan. 2005. Mewujudkan Kesejahteraan Bangsa : Menanggulangi Angka Kemiskinan dengan Prinsip Pemberdayaan Masyarakat. Jakarta : PT Elex Media Komputindo.

Monografi Desa Ompu Raja Hutapea Timur Kecamatan Laguboti - Kabupaten Toba Samosir.

Paket Informasi PNPM Mandiri 2012-2013.

Petunjuk Teknis Operasional PNPM Mandiri Perdesaan.

Proposal Penelitan Christin Mandasari, 2012. Evaluasi Dampak Program Pemberdayaan Masyarakat (PNPM Mandiri) Dalam Menanggulangi Kemiskinan di Kabupaten Simalungun. Medan : Universitas Sumatera Utara. 